\title{
Field evidence concerning the origin of the early leucocratic granites within the Qôrqut Granite Complex in the area of Qôrqut
}

\author{
Michael Brown and C. R. L. Friend
}

We have shown (Brown \& Friend, this report) that the Qôrqut Granite Complex in the area east of Úmánap suvdlua is made up of three main groups of granites. This report describes structures found in the area of Qôrqut which provide an insight into the origin of the first main group - the leucocratic granites.

\section{The leucocratic granites}

The slopes of Qôrqut provide a section through the lower zone of the Qôrqut Granite Complex. In this zone, the leucocratic granites form the dominant component of the polyphase granite. Structures within the leucocratic granites are seen best in fresh rock-fall blocks along the slopes north of Ujarã and on glacially polished surfaces along either shore of Qôrqut (fig. 27, Brown \& Friend, this report). The leucocratic granites vary from homogeneous leucogranites through leucogranites with biotite lamellae to inhomogeneous biotite granites with schlieren structure. The latter contain discrete to diffuse enclaves of gneiss which exhibit a range of states of modification from their original textures and structures by segregation and disruption. The enclaves ultimately become indistinguishable from the inhomogeneous biotite granite with schlieren structure. These enclaves of modified gneiss contrast markedly with infrequent rafts and enclaves of essentially unmodified gneiss which occasionally occur near sea level along the shores of Qôrqut. This unmodified gneiss within the leucocratic granites appears to have retained its original orientation and to be of local derivation. The presence of strips of amphibolite which we interpret as being Ameralik dykes within many of these rafts and enclaves suggests that they are dominantly Amîtsoq gneisses.

The modified gneiss enclaves within the inhomogeneous biotite granite. Some of the enclaves of modified gneiss exhibit granite layers $1-2 \mathrm{~cm}$ thick (leucosomes) bounded by semi-continuous to continuous biotite selvedges (melanosomes) up to several millimetres in thickness which are separated by bands of gneiss generally $5-10 \mathrm{~cm}$ thick (palaeosomes) (fig. 25). These enclaves represent metatexites, that is migmatites characterised by a segregation banding produced by metamorphic differentiation or partial melting (Brown, 1973).

More commonly, the enclaves of modified gneiss contain no obvious palaeosomes although they retain a layered structure defined by granitic leucosomes, $2-5 \mathrm{~cm}$ thick, separated by biotite-rich melanosomes of variable thickness up to $5 \mathrm{~mm}$ and, less commonly, 10 $\mathrm{mm}$ thick. This layering often has a folded form which represents a relict tectonic structure preserved from the original gneiss, although no tectonite fabric remains. These enclaves are thus comprised entirely of neosome with a layered structure probably derived from the parent gneiss. With progressive modification the biotite-rich layers become disrupted to form schlieren generally 5-20 cm long, but with a rather irregular distribution (fig. 26). At this point in the modification process enclaves of gneiss become indistinguishable from the inhomogeneous biotite granite with schlieren structure. We interpret the enclaves in which 
Fig. 25. A modified gneiss (metatexite) enclave in an inhomogeneous biotite granite member of the early leucocratic granite. North side of Qôrqut.

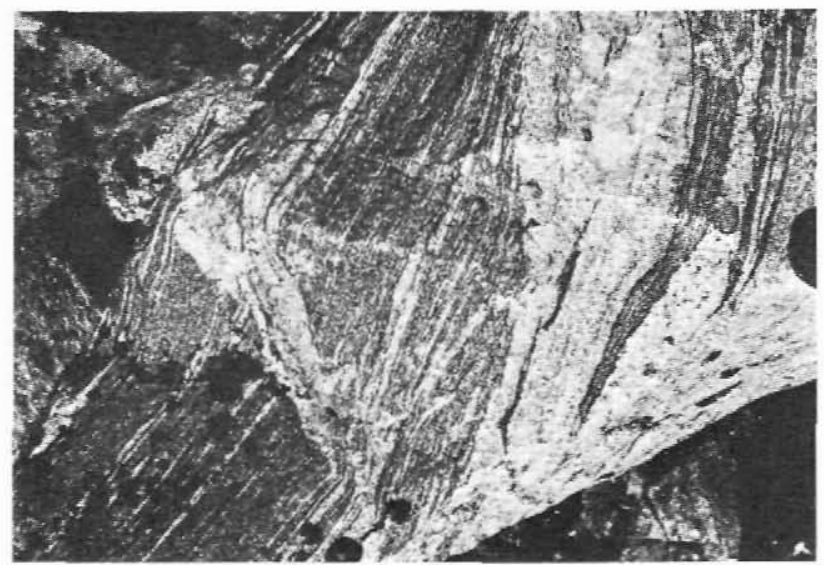

no palaeosome of gneiss remain as diatexites, that is anatectic granites produced by extensive partial melting sufficient to destroy the regular migmatitic banding characteristic of metatexites (Brown, 1973).

Frequently, enclaves of metatexite can be seen to pass laterally and vertically into inhomogeneous diatexite with progressive elimination of the gneiss palaeosome and the progressive disruption of the biotite-rich melanosome as a result of increasing degree of anatexis. The continuum between metatexite and diatexite is thus clearly established. This continuum is further confirmed in enclaves comprising gneiss layers which exhibit different migmatite structures as a result of differing degrees of anatexis consequent upon different bulk chemical composition.

Rarely, the gneiss component of the metatexite enclaves includes strips of amphibolite,

Fig. 26. Inhomogeneous biotite granite interpreted as diatexite with schlieren structure. South side of Qôrqut.

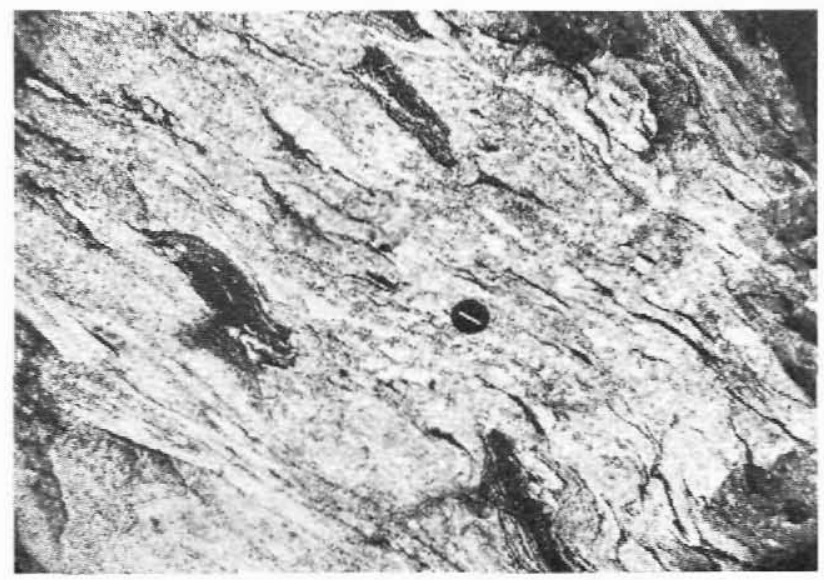


some of which are feldspar megacrystic; we interpret these amphibolites as being relict Ameralik dykes. In one example, an amphibolite can be followed from metatexite palaeosome laterally into inhomogeneous diatexite. Frequently, the inhomogeneous biotite granites contain boudinaged strips and agmatised blocks of amphibolite characteristically with biotite-rich margins due to metasomatic recrystallisation and which are occasionally feldspar megacrystic; these amphibolites are considered to have been derived from Ameralik dykes. The parent rock type of the modified gneiss enclaves seems, therefore, to have been largely Amîtsoq gneisses, probably tonalites and granodiorites of grey gneiss type.

\section{The origin of the leucocratic granites}

That inhomogeneous diatexite with schlieren structure is developed largely from Amitsoq gneisses by extensive anatexis and disruption of the gneiss layering can be established from modified gneiss enclaves within the leucocratic granites. It is our contention that the inhomogeneous biotite granite member of the leucocratic granite group is generated by such a process within a zone of melting in Amitsoq gneisses in the vicinity of Qôrqut but below the present level of erosion, albeit not far below. The enclaves of modified gneiss could represent fragments of the ?upper margin of this melting zone incorporated within mobile inhomogeneous biotite granite as it moved from a zone of generation and collection to a stable level of congelation within the crust.

Examination of the inhomogeneous biotite granites with schlieren structure in fresh blocks in rock falls and in freshly exposed bed rock in the cliffs above, north of Ujarã, demonstrates that biotite schlieren may become smeared out and disaggregated through viscous flow and consequent differentiation to produce a leucogranite with biotite lamellae of the order of 1-2 mm thick. These lamellae are spaced at intervals from less than $10 \mathrm{~cm}$ to more than $50 \mathrm{~cm}$, beyond which we classify the granite as homogeneous leucogranite. Thus we consider there to be a continuum between the inhomogenous biotite granites with schlieren structure, through leucogranites with biotite lamellae, to homogeneous leucogranites.

\section{Conclusions}

Field evidence in the area of Qôrqut strongly suggests that the early leucocratic granites within the Qôrqut Granite Complex were derived by extensive anatexis of gneisses, predominantly of Amîtsoq type, not far below the present erosion level through the complex. The three members of the leucocratic granite group - the inhomogeneous biotite granite with schlieren structure, the leucogranites with biotite lamellae and the homogeneous leucogranites - are related, the latter two being derived from the first by flow differentiation during upward movement and emplacement of the relatively locally derived partial melt/residuum mixture.

\section{Acknowledgements}

We thank A. D. M. Burwell, V. R. McGregor and C. G. Topley for reading the manuscript. 


\section{Reference}

Brown, M. 1973: The definition of metatexis, diatexis and migmatite. Proc. Geol. Ass. 84, 371-382.

Department of Geology \& Physical Sciences, Oxford Polytechnic, Headington, Oxford $O X 3 O B P$,

U.K.

\section{The polyphase nature and internal structure of the Qôrqut Granite Complex east of Ümánap suvdlua, Godthåbsfjord, southern West Greenland}

\section{Michael Brown and C. R. L. Friend}

Fieldwork during 1979 enables us to describe the internal structure of the Qôrqut granite (McGregor, 1973) in the area to the east of Ümánap suvdlua (fig. 27) and to elucidate the polyphase nature of the magmatism. As a result, it is proposed that future reference be made to the Qôrqut Granite Complex rather than to the Qôrqut granite; this proposal is justified below.

\section{The polyphase nature of the Qôrqut Granite Complex}

The Qôrqut Granite Complex is comprised of a number of different phases and at many localities the relationships between these phases are complex. We divide the phases into three main groups:

(1) leucocratic granites, often characterised by the presence of biotite schlieren and lamellae;

(2) essentially homogeneous, grey biotite granites;

(3) composite aplogranite - granite pegmatite sheets.

\section{Leucocratic granites}

The earliest component of the Qôrqut Granite Complex is the group of leucocratic granites, members of which are particularly well displayed along the coast and slopes of Qôrqut and along the east coast of Ümánap suvdlua. These granites are generally coarse grained with a hypidiomorphic granular texture and vary from massive, homogeneous leucogranites, through leucogranites with biotite lamellae spaced from over $50 \mathrm{~cm}$ to under $10 \mathrm{~cm}$ apart, to inhomogeneous biotite granites with schlieren structure and within which relict gneissose structures (but not textures) are preserved. The latter are considered to be diatexites resulting from extensive anatexis of gneiss (Brown \& Friend, this report). Around Ujarã, ghost-like remnants of gneiss, produced by varying degrees of anatexis and resultant disrup- 